\title{
THE NEXUS BETWEEN FISCAL DEFICIT AND ECONOMIC GROWTH IN MALAYSIA
}

\author{
Ahmad Azrie Ahmad Bhari, ${ }^{*}$ Wee-Yeap Lau, ${ }^{* *}$ \\ Mohamed Aslam** \& Tien-Ming Yip ${ }^{* *}$ \\ ( ${ }^{*}$ First author) \\ ${ }^{*}$ Ministry of International Trade \& Industry (MITI), Malaysia \\ ** Faculty of Economics and Administration, University of Malaya, \\ Kuala Lumpur, Malaysia. \\ (azrie@miti.gov.my,wylau@um.edu.my, maslam@um.edu.my, \\ yiptienmeng@um.edu.my) \\ Doi: https://doi.org/10.22452/jati.vol25no1.5
}

\begin{abstract}
This study investigates the linkages between fiscal deficit and economic growth in Malaysia. Using data from 1980 to 2017, our results indicate: Firstly, there exists a long-run relationship between fiscal deficit and real GDP; secondly, on information flow, the fiscal deficit is found to precede real GDP. Further analysis of the impact of fiscal deficit on real GDP proves that the Keynesian Growth Theory is valid in Malaysia. Specifically, the fiscal deficit has a positive impact on Malaysia's GDP. Moreover, the fiscal deficit is found to be growth-enhancing during the 1997-98 and 2008-09 economic crisis. Hence, it can be concluded that the fiscal deficit is imperative in helping the Malaysian economy restore itself after an economic crisis. As a policy suggestion, fiscal deficit results from the expansionary fiscal policy should be countercyclical to smoothen the business cycle and subsequently improve Malaysia's macroeconomic performance.
\end{abstract}

Keywords: fiscal deficit, economic growth, countercyclical, business cycle

\section{Introduction}

Malaysia is a small open economy country, yet its progress has been remarkable in the recent years compared to other developing countries. Despite having stable economic growth, Malaysia has been using its fiscal policy as an economic stabilisation tool. This policy influences the direction of the economy and is vital in shaping Malaysia's macroeconomic indicators. 
Fiscal expansion tends to accelerate fiscal deficit in the economy. In 1982, Malaysia experienced a fiscal deficit, which was near to 20 per cent of its GDP. Since then, Malaysia has taken the fiscal issue seriously and progressively reduced the fiscal deficit. As a result, Malaysia managed to achieve a fiscal surplus in between five years - from 1994 to 1997.

However, Malaysia reverted to the budget deficit in 1998 due to the Asian Financial Crisis in 1997-98. This was an unprecedented period in Malaysian history. Not only the currency value decreased from RM2.50 per USD to RM4.80 per USD in a span of a few months, but the market capitalisation of the Kuala Lumpur Stock Exchange also lost 53.42 percent Year-on-Year from 1996 to the 1997 Year Ends. The size of the unit trust fund industry was reduced from RM60 billion to RM33 billion, a loss of 45 per cent of its Net Asset Value (Lau, 2007).

The fiscal surplus recorded in early 1997 soon declined into the region of a deficit as the Asian Financial Crisis struck the region in July 1997. Figure 1 shows the trend of real GDP and fiscal deficit in Malaysia from 1980 to 2017. It can be observed the fiscal deficit grew even deeper until 2000. During the corresponding period from 1997 to 2000, there was a rise in the real GDP. This implies the fiscal deficit incurred in earlier years has enabled the economy to recover, albeit at a slower pace.

During the 2008-09 Global Financial Crisis, the fiscal deficit was lower than 5 per cent of the GDP. The Global Financial Crisis (GFC) caused a severe blow to some of the ASEAN member countries, especially to their primary engine of growth. Most countries rely on the export sector to grow their economies. Lesser export or negative growth in their respective economies means income and living standards will fall, but the impact of the crisis varied from one country to another. 


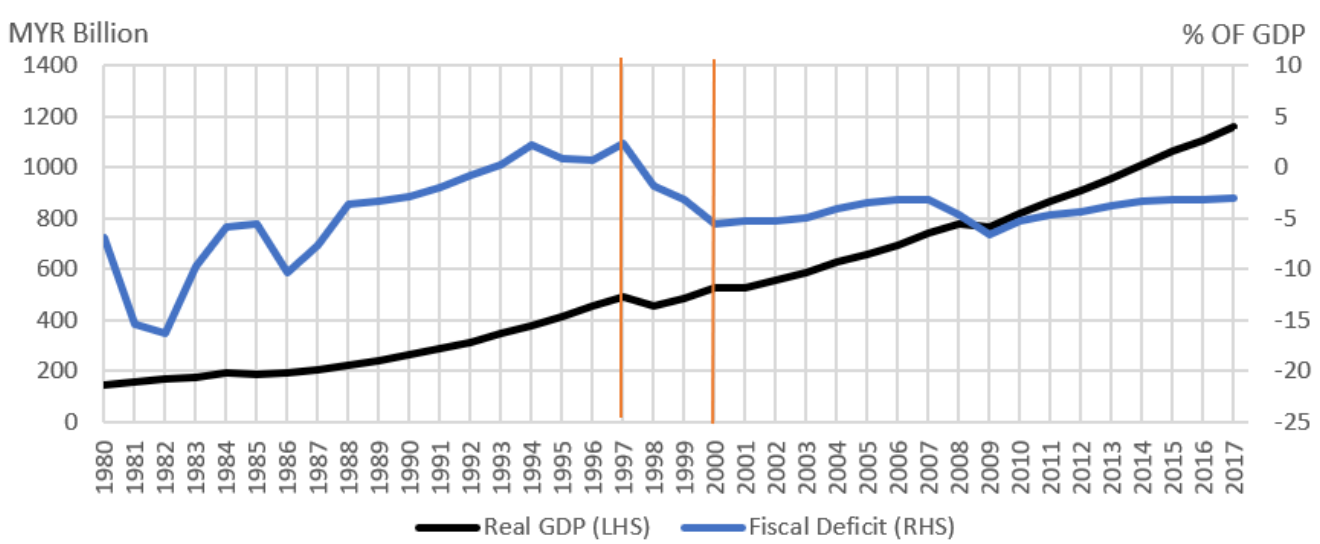

Figure 1: Trend of real GDP and Fiscal Deficit in Malaysia

(Source of Real GDP: WEO April 2017 Database. Source of Fiscal Deficit: Ministry of Finance Malaysia)

As observed in Table 1, Malaysia led the pack of contrary countries with $2.56 \%$, followed by Brunei $(-1.78 \%)$, Thailand $(-0.69 \%)$, and Singapore $(-0.61 \%)$ in 2009. Furthermore, Cambodia and the Philippines also experienced a low growth situation in 2009. In contrast, Myanmar, Lao PDR, Vietnam, and Indonesia were able to maintain a decent growth rate, partly due to the capital flow from foreign direct investment to the respective countries.

Furthermore, for all ASEAN members, the policy responses show a similar pattern. Each country used the fiscal stimulus to stimulate the economy during the post-Global Financial Crisis periodically. Table 1 presents data for the fiscal deficit for all ASEAN countries. As observed, Malaysia generated a rather sizeable fiscal deficit, i.e., 6.7 per cent of gross domestic product (GDP) in 2009.

The fiscal deficit incurred in 2008 and 2009 had enabled the Malaysian economy to recover from the economic stagnation, as evidenced by the annual GDP growth of $6.75 \%$ in 2010 . On this basis, this study attempts to investigate the linkages between fiscal deficit and economic growth in Malaysia.

The rest of this study is organized as follows. Section 2 provides a review of the existing literature on the deficit-growth nexus, followed by the analytical framework of the study. Section 3 describes the data and methodology. Section 4 discusses the findings, and the last section concludes the study. 
Table 1: GDP Growth and Fiscal Balance in the ASEAN Countries (2008-2010)

\begin{tabular}{lcccccr}
\hline & \multicolumn{3}{c}{ GDP growth (annual \%) } & \multicolumn{3}{c}{ Fiscal deficit (\% of GDP) } \\
\cline { 2 - 7 } \multicolumn{1}{c}{ ASEAN-10 } & 2008 & 2009 & 2010 & 2008 & 2009 & 2010 \\
\hline Brunei & -1.96 & -1.78 & 2.57 & 27.92 & -2.36 & 15.64 \\
Cambodia & 6.48 & 0.09 & 5.79 & -2.9 & -6.2 & -8.8 \\
Indonesia & 5.84 & 4.52 & 6.04 & -0.1 & -1.6 & -0.7 \\
Lao PDR & 7.53 & 7.23 & 8.18 & -2.2 & -3.2 & -2.2 \\
Malaysia & 3.27 & -2.56 & 6.75 & -4.6 & -6.7 & -5.3 \\
Myanmar & 9.76 & 10.03 & 9.2 & -2.38 & -4.56 & -4.64 \\
Philippines & 4.07 & 1.14 & 7.36 & -0.9 & -3.7 & -3.5 \\
Singapore & 1.77 & -0.61 & 14.18 & 7.1 & 7.33 & 7.57 \\
Thailand & 1.71 & -0.69 & 7.24 & -0.6 & -3.9 & -2.9 \\
Vietnam & 5.51 & 5.26 & 6.23 & 0.6 & -4.2 & -2.1 \\
\hline
\end{tabular}

Notes: GDP growth is computed based on the GDP at constant USD, 2010 price.

Source of GDP growth: World Development Indicator.

Source of the fiscal deficit: Asian Development Bank.

\section{Literature Review}

Various empirical studies have been done to clarify the relationship between fiscal deficit and economic growth. The study on the fiscal deficit-economic growth nexus can be traced back to Martin and Fardmanesh (1990). By using cross-section data from 76 developed and developing countries from 1972 to 1981, that study attempts to investigate the impact of different fiscal variables on economic growth. Specifically, the fiscal variables are government fiscal deficit, expenditure, revenue, non-tax revenue, gross capital formation, and population growth. The cross-sectional linear regression shows that deficit and tax revenue have a negative impact on economic growth. At the same time, government expenditure is found to have a positive impact on growth.

Furthermore, by dividing countries into low, middle, and high-income categories, the study found that there exists a negative relationship between fiscal deficit and economic growth only in middle-income countries. In contrast, Nelson and Singh (1994) examines the deficit-growth nexus for 70 developing countries and found that there was no significant relationship between fiscal deficit and economic growth.

In a panel data approach, Adam and Bevan (2005) investigates the relationship between fiscal deficit and economic growth for 45 countries from 1970 to 1999 . Results indicate that there exists a threshold effect in the deficitgrowth relation. If the fiscal deficit is less than or equal to $1.5 \%$ of GDP, then 
deficits are found to be growth-enhancing. In contrast, deficits above the threshold level are found to be growth-deteriorating. Moreover, a robustness check by replacing government expenditure for fiscal deficit shows that productive expenditure has a positive economic growth. In contrast, extra expenditure is found to have a negative relationship with growth.

Furthermore, by focusing on the individual country, Tan (2006) examines the dynamic linkages between fiscal deficit, inflation, and economic growth in Malaysia from 1966 to 2003. It is found that there is unidirectional causality from fiscal deficit to money supply and from money supply to prices. That study concludes that fiscal deficit could have an inflationary impact on the economy through the monetisation of deficits.

Subsequently, Taylor, Proano, Carvalho and Barbosa (2012) examine the relationship between fiscal deficit, government debt, and economic growth for the U.S. economy. Using quarterly data from 1961 to 2011 results from vector error correction (VEC) shows that fiscal deficit has a significant positive effect on economic growth. Moreover, the paper strongly argues that a higher fiscal deficit tends to stimulate the economy during the recession.

Next, Van and Sudhipongpracha (2015) examines the relationship between government budget deficit and economic growth from 1989 to 2011 in the Vietnamese economy. Results from the panel analysis demonstrate that the deficits do not affect the country's economic productivity. Instead, the study reveals that foreign direct investment is vital in influencing Vietnam's economic productivity over the same period, while the real interest rate is found to affect growth adversely. The study concludes that Vietnam requires administrative and regulatory reforms to ensure a continuous flow of foreign capital rather than an expansion of the public sector through government spending deficit. Furthermore, for Bangladesh, Rana and Wahid (2017) find that the government budget deficit had a statistically significant negative impact on economic growth over the period 1981 to 2011.

Rana and Wahid (2017) also presents an econometric study of the impact of government fiscal deficit on the economic growth of Bangladesh from 1981 to 2011. Using real GDP as a proxy of economic growth, the findings suggest that the government's fiscal deficit has a statistically significant negative impact on Bangladesh's economic growth. Subsequently, the result of a pairwise Granger Causality test that determines the directional relationship between the variables indicates the existence of unidirectional causality running from fiscal deficit to real GDP.

Moreover, a recent study by Mohanty (2018) shows that there exists a long-run relationship between fiscal deficit and economic growth in the Indian 
economy. Results from Autoregressive Distributed Lag (ARDL) model indicate that fiscal deficit has an adverse effect on growth in both the short and long run in India.

Besides, this study reveals that the implementation of the Fiscal Responsibility and Budget Management (FRDM) Act has weakened the relationship between fiscal deficit and economic growth. Therefore, the paper concludes that the Indian government should contain the fiscal deficit via the FRBM Act.

The above empirical evidence on the relationship between fiscal deficit and economic growth are mixed. Moreover, to the best of our knowledge, the study on the deficit-growth nexus remains scarce in Malaysia. Therefore, this paper provides new evidence that sheds light on the linkages between fiscal deficit and economic growth in Malaysia. Not only that, this paper reveals the influence of fiscal deficit on Malaysia's GDP during the 1997-98 and 2008-09 economic crisis.

\section{Analytical Framework}

\section{Fiscal Deficit and Economic Growth Nexus}

There are two significant schools of thought that have different views on the fiscal deficit and economic growth. Neoclassical economists state that the fiscal deficit will bring a negative impact on economic growth. As such, the fiscal deficit will raise an individual's total lifetime consumption by shifting taxes to subsequent generations. If economic resources are fully employed, the increase in consumption implies a decrease in savings. Therefore, the interest rate must rise to bring capital markets into equilibrium. Thus, a persistent deficit will eventually "crowd out" private capital accumulation and subsequently deteriorate economic growth.

Conversely, from the Keynesian school, the Keynesian Growth Theory views a positive relationship between fiscal deficit and growth. The theory argues that there is a significant fraction of the population in the economy of which is thought to face liquidity constraints. These individuals have very high propensities to consume out of current disposable income. Hence, a temporary tax reduction will have an immediate and quantitatively significant impact on aggregate demand.

Furthermore, if the economy's resources are initially underemployed, the rise in consumption will lead to an increase in national income, thereby generating the second-round effect and the well-known Keynesian multiplier. Moreover, fiscal deficit stimulates the capital accumulation process through the rise in public sector investment, thereby strengthening the economic growth. 
(Bernheim, 1989). Accordingly, the following function shows the relationship between fiscal deficit and economic growth.

$$
\mathrm{GDP}=F \text { (F.D., RER, INT INV) }
$$

The selection of the above variables is based on Majumder (2007), and Fatima, Ahmed and Rehman (2012). The GDP represents the Malaysian real Gross Domestic Product - a proxy of economic growth; F.D., RER, INT, and INV denote fiscal deficit, real exchange rate, real interest rate, and total investment.

For the subsequent analysis, a test for cointegration will be conducted to ensure long-term relationships in the deficit-growth nexus. Next, Granger's causality test will be used to establish the information flow between fiscal deficit and economic growth. Moreover, the positive and negative impact of fiscal deficit on economic growth will be analysed by employing the Ordinary Least Square method.

\section{Hypothesis}

This paper attempts to examine the linkages between fiscal deficit and economic growth in Malaysia. However, the information flow between fiscal deficit and other macroeconomic indicators will be discussed as well. Furthermore, this study investigates the impact of fiscal deficit on Malaysia's GDP. Hence, it can be hypothesised that:

Table 2: Hypotheses Development

A. Information flow between fiscal deficit and macroeconomic indicators

\begin{tabular}{ll}
\hline Hypotheses & Description \\
\hline 1 & There is information flow from fiscal deficit to real GDP. \\
2 & There is information flow from fiscal deficit to real exchange rate \\
3 & There is information flow from fiscal deficit to the real interest rate. \\
4 & There is information flow from fiscal deficit to total investment. \\
\hline
\end{tabular}

B. Impact of fiscal deficit on real GDP

\begin{tabular}{ll}
\hline Hypotheses & Description \\
\hline 5 & There is a positive association between fiscal deficit and real GDP. \\
6 & There is a negative association between fiscal deficit and real GDP. \\
\hline
\end{tabular}

All the hypotheses in Panel A of Table 2 establish the information flow between fiscal deficit and macroeconomic indicators in Malaysia. Hypothesis 1 is set to confirm that there is information flow from fiscal deficit to the real GDP. 
Fiscal deficit improves the aggregate demand through the rise in public sector investments, thereby leading to the rise in economic growth.

Furthermore, fiscal deficit stimulates capital accumulation in the domestic economy, thereby improving foreign investors' sentiment. Subsequently, the demand for Ringgit Malaysia increases, leading to appreciation in currency value. Therefore, hypothesis 2 is set up to validate the information flow from a fiscal deficit to the real exchange rate.

Next, hypothesis 3 demonstrates that there is information flow from fiscal deficit to the real interest rate. An increase in the fiscal deficit will lead to the rise in interest rate as the government increases the demand for loanable funds to finance the deficit.

Lastly, fiscal deficit accelerates the growth of capital stocks through public sector investments which will improve local firms' sentiment, thereby facilitating private investments. Hypothesis 4 is set up to test for such possibilities.

After establishing the causality between fiscal deficit and GDP, the next question is the fiscal deficit on Malaysia GDP. As observed in Panel B of Table 2, hypothesis 5 is set to test the validity of the Keynesian Growth Theory in Malaysia's case. Fiscal deficit improves private firms' sentiment through the rise in public sector investment, thereby stimulating private investments. As a result, higher investment contributes to the rise in real GDP. Therefore, there is a positive association between fiscal deficit and GDP.

Hypothesis 6 illustrates the crowding-out hypothesis, which proposed by the Neoclassical Economic Theory. An increase in the fiscal deficit will crowd out private investments due to the rise in interest rates. The higher interest rate tends to impose liquidity constraints on firms and will subsequently distort the economy's capital accumulation process. As a result, private investments decrease and leads to lower GDP.

\section{Data and Methodology}

\section{Data}

This study uses data from 1980 to 2017 to investigate the linkages between fiscal deficit and economic growth in Malaysia. Table 3 shows the variables used and the sources of the data. 
Table 3: List of variables

\begin{tabular}{lll}
\hline Variables & Description & Source \\
\hline GDP & Real GDP (2010 constant price, MYR Billion) & WEO April 2017 Database \\
F.D. & Fiscal deficit (\% of GDP) & Ministry of Finance Malaysia \\
RER & Real Exchange Rate (local currency per 1 USD) & IMF International Financial Statistics \\
INT & Real Interest Rate (\%) & IMF International Financial Statistics \\
INV & Total investment (\% of GDP) & WEO April 2017 Database \\
\hline
\end{tabular}

Note: The sample period is from 1980 to 2017.

\section{Unit Root Test}

The unit root test will be conducted to ensure the stationarity of variables being used. For this study, the Phillips-Perron unit root test is more appropriate for small sample studies (Hallam \& Zanoli, 1993; Obben, 1998). The P.P. test equation is:

$$
\Delta y_{t}=\mu+\beta t+\gamma y_{t-1}+\varepsilon_{t}
$$

The hypothesis to be tested is

Ho: $\gamma=0$ (The series needs to be differenced to make it stationary); $\mathrm{H}_{1}: \gamma<0$ (The series is stationary and need not be differenced)

As a robustness check on the result of the unit root test, the stationary test has been carried out. KPSS test by Kwiatkowski, Philips, Schmidt and Shin (1992) is used. Under the null hypothesis, the series $\mathrm{yt}_{\mathrm{t}}$ is assumed to be stationary. Whereas, under the alternative hypothesis, the series yt is non-stationarity.

\section{Multivariate Cointegration Analysis and Error-Correction Modelling}

In testing for cointegration, this paper uses the Johansen (1988) procedure. This procedure is a multivariate cointegration analysis, in which it allows one to test for the number of cointegrating vectors that might exist. Johansen's (1988) multivariate cointegration model is based on the error correction representation given by:

$$
\Delta X_{t}=\mu+\sum_{i=1}^{p-1} \Gamma_{i} \Delta X_{t-i}+\operatorname{IIX} X_{t-1}+\varepsilon_{t}
$$

Where $X_{t}$ is an $(n \times 1)$ column vector of $p$ variables, $\mu$ is an $(n \times 1)$ vector of constant terms, $\Gamma$ and II represents coefficient matrices, $\Delta$ is a differenced 
operator, and $\varepsilon_{t}$ is the error term. The coefficient matrix II is known as the impact matrix, and it contains information about the long-run relationships. Johansen's methodology requires the estimation of the VAR. The residuals are then used to compute two likelihood ratio test statistics that can be used in the determination of the unique cointegrating vector $X_{t}$. The cointegrating rank can be tested with two statistics: the trace test and the maximal eigenvalue test.

\section{Results}

\section{Descriptive Statistics}

As observed in Table 4, on average, Malaysia's real GDP was RM 530.108 billion, and the total investment constitutes 30.57 per cent of the GDP throughout the sample period. Moreover, Malaysia experienced an average fiscal deficit of 4.36 per cent of GDP from 1980 to 2017.

Table 4: Descriptive Statistics

\begin{tabular}{lrrrrrr}
\hline Variables/Periods & Mean & Std Dev & Skewness & Kurtosis & J-B statistic & Obs \\
\hline GDP & 530.108 & 303.701 & 0.474 & 2.079 & $2.766(0.251)$ & 38 \\
F.D. & -4.355 & 3.894 & -1.133 & 5.267 & $16.262(0.000)$ & 38 \\
RER & 3.153 & 0.647 & 0.217 & 1.767 & $2.706(0.258)$ & 38 \\
INT & 3.095 & 1.881 & 0.529 & 2.129 & $2.970(0.226)$ & 38 \\
INV & 30.566 & 8.248 & 0.674 & 2.028 & $4.375(0.112)$ & 38 \\
\hline
\end{tabular}

Notes: All statistics are based on the original data. Values in parenthesis are p-values. Sample period: 1980-2017. GDP denotes Real GDP (MYR Billion); F.D. denotes Fiscal Deficit (\% of GDP); RER denotes Real Exchange Rate (Local currency per 1 USD); INT denotes Real Interest Rate (\%). INV denotes Total Investment (\% of GDP).

\section{Unit Root Test}

As observed in Table 5, all the series becomes stationary after taking the first difference. Hence, they are integrated of order one or following the I(1) process. Under Granger's representation theorem, if a set of non-stationary variables are cointegrated, then they can be characterised as generated by an error correction mechanism. To know whether there exists such cointegration for these nonstationary variables, the Johansen's cointegration test has been conducted. 
Table 5: Unit Root and Stationarity Test

\begin{tabular}{|c|c|c|c|c|c|}
\hline \multirow[b]{2}{*}{ Variables } & \multicolumn{2}{|r|}{ PP } & \multicolumn{3}{|c|}{ KPSS } \\
\hline & Intercept & Trend and intercept & Intercept & Trend a & rcept \\
\hline \multicolumn{6}{|c|}{ Level } \\
\hline Ln GDP & $-1.20(2)$ & $-1.32(2)$ & $0.74(5)^{* *}$ & $0.15(5)^{* *}$ & \\
\hline FD & $-1.84(10)$ & $-2.12(7)$ & $0.79(0)^{* *}$ & $0.16(4)^{* *}$ & \\
\hline Ln RER & $-1.47(3)$ & $-2.33(0)$ & $0.62(5)^{* *}$ & $0.18(1)^{* *}$ & \\
\hline Ln INT & $-0.28(1)$ & $-2.60(1)$ & $0.70(5)^{* *}$ & $0.17(1)^{* *}$ & \\
\hline Ln INV & $-1.60(1)$ & $-2.19(2)$ & $0.50(4)^{* *}$ & $0.25(0)^{* *}$ & \\
\hline \multicolumn{6}{|c|}{ First Differencing } \\
\hline Ln GDP & $-4.91(1)^{* * *}$ & $-4.98(1)^{* * *}$ & $0.20(2)$ & $0.07(2)$ & $I(1)$ \\
\hline FD & $-6.34(7)^{* * *}$ & $-6.95(12)^{* * *}$ & $0.07(2)$ & $0.07(2)$ & $I(1)$ \\
\hline Ln RER & $-6.03(4)^{* * *}$ & $-5.93(4)^{* * *}$ & $0.07(5)$ & $0.07(5)$ & $I(1)$ \\
\hline Ln INT & $-5.14(6)^{* * *}$ & $-5.01(6)^{* * *}$ & $0.10(1)$ & $0.07(1)$ & $I(1)$ \\
\hline Ln INV & $-4.88(0)^{* * *}$ & $-4.83(1)^{* * *}$ & $0.08(0)$ & $0.08(0)$ & $I(1)$ \\
\hline
\end{tabular}

Notes: ${ }^{*}{ }^{* *}$ and ${ }^{* * * *}$ denote $10 \%, 5 \%$ and $1 \%$ significance level, respectively.

Ln denotes all series have transformed into a natural logarithm.

Figures in parentheses indicate optimal lag length chosen.

\section{Testing for Long Run-relationship}

As shown in Table 6, the result shows two cointegrating vectors from the Trace test. Therefore, it can be concluded that there is a long-run relationship between the series. In other words, two common stochastic trends bind the set of variables together. Next, we proceed to look at Granger's causality between the variables.

Table 6: Johansen Cointegration test

\begin{tabular}{lcc}
\hline Hypothesised number of C.E. & \multicolumn{2}{c}{ Trace test } \\
\cline { 2 - 3 } & Trace statistics & $5 \%$ critical value \\
\hline None $^{*}$ & 89.7254 & 69.8189 \\
At most $1 *$ & 53.9840 & 47.8561 \\
At most 2 & 26.9947 & 29.7971 \\
At most 3 & 10.7684 & 15.4947 \\
At most 4 & 1.5897 & 3.8415 \\
\hline
\end{tabular}

\section{Granger's Causality Test Results}

As observed in Table 7, there is information flow from a fiscal deficit (F.D.) to real GDP. This result supports hypothesis 1 at 5 per cent level. Fiscal deficit stimulates aggregate demand through the rise in public sector investments, thereby facilitating the country's GDP.

Next, the fiscal deficit dictates the movement of the real interest rate (Hypothesis 3). A rise in the fiscal deficit indicates demand for loanable funds 
increases as the government demands more funds to finance the deficit. Subsequently, the interest rate increases.

Conversely, there is no information flow from fiscal deficit to real exchange rate and total investment. Therefore, both hypotheses 2 and 4 cannot be accepted.

The changes in the exchange rate heavily rely on the stance of monetary policy. As such, changes in the monetary policy would affect the flow of portfolio investment, thereby affecting the exchange rate movements. Therefore, fiscal deficit results from the fiscal expansion will not affect the exchange rate.

Moreover, the interest rate is not the sole determinant of investments. Investments might be affected by other variables such as investor's expectations and current economic performance. Therefore, the fiscal deficit, which alters the interest rate, will not affect Malaysia's total investments.

Turning to the estimated coefficients of Error-Correction Term (ECT), by and large, all the coefficients are correctly signed, and three of them are statistically significant. The results further support the finding of a cointegrated relationship between the series reported earlier in Table 6 .

Table 7: Granger's Causality Test Results

\begin{tabular}{llllllll}
\hline $\begin{array}{l}\text { Dependent } \\
\text { variables }\end{array}$ & \multicolumn{7}{c}{ Variables } \\
\cline { 2 - 8 } & $\Delta$ Ln GDP & $\Delta$ FD & $\Delta$ Ln RER & $\Delta$ Ln INT & $\Delta$ Ln INV & ECT1 $1_{\mathrm{t}-1}$ & ECT2 $_{\mathrm{t}-1}$ \\
\hline$\Delta$ Ln GDP & & $9.276^{* *}$ & $20.187^{* * *}$ & $10.118^{* *}$ & $15.643^{* * *}$ & $-0.074^{* *}$ & -0.001 \\
& & $(0.026)$ & $(0.000)$ & $(0.018)$ & $(0.001)$ & $(0.025)$ & $(0.631)$ \\
$\Delta$ FD & $23.706^{* * *}$ & & $25.298^{* * *}$ & $23.268^{* * *}$ & $23.495^{* * *}$ & -1.303 & $-0.385^{* * *}$ \\
& $(0.000)$ & & $(0.000)$ & $(0.000)$ & $(0.000)$ & $(0.434)$ & $(0.000)$ \\
$\Delta$ Ln RER & 4.905 & 0.617 & & 2.817 & 2.506 & 0.054 & -0.003 \\
& $(0.179)$ & $(0.893)$ & & $(0.421)$ & $(0.474)$ & $(0.577)$ & $(0.543)$ \\
$\Delta$ Ln INT & $11.659^{* * *}$ & $15.829^{* * *}$ & $9.966^{* *}$ & & $19.779^{* * *}$ & $-0.306^{* * *}$ & 0.001 \\
& $(0.009)$ & $(0.001)$ & $(0.019)$ & & $(0.000)$ & $(0.007)$ & $(0.899)$ \\
$\Delta$ Ln INV & 1.084 & 1.634 & $13.120^{* * *}$ & 4.916 & & -0.101 & 0.003 \\
& $(0.781)$ & $(0.652)$ & $(0.004)$ & $(0.178)$ & & $(0.337)$ & $(0.549)$
\end{tabular}

Notes: ${ }^{*}{ }^{* *}$ and ${ }^{* *}$ denote statistical significance at $10 \%, 5 \%$ and $1 \%$ level respectively. $\Delta$ denotes the first difference. All estimates are asymptotic Granger Chi-squared statistics. Values in parentheses are p-values. Optimal lag length selection based on SIC is 1. Ln denotes all series have been transformed to the natural logarithm. 


\section{Long-run Equilibrium and OLS Estimation}

Since the cointegration test results in the model indicate the presence of at least one cointegrating vector between the variables, conducting regression between these variables with the OLS method will not provide spurious results. Instead, the long-run relationship between the variables can be well explained. Hence, this study further reveals the impact of fiscal deficit on Malaysia's GDP.

To ensure the validity of the OLS results, diagnostic checks such as the Breusch-Godfrey test, Ramsey RESET test, and CUSUM of Squares test are carried out. Moreover, dummy variables that capture the 1997-98 ASEAN Financial Crisis (AFC) and 2008-09 Global Financial Crisis (GFC) have been included.

As observed in Table 8, the fiscal deficit (F.D.) significantly affects Malaysia's real GDP. In particular, fiscal deficit (F.D.) is found to have an expansionary effect on real GDP in all the five models. An increase in fiscal deficit through public sector investment will stimulate capital accumulation, thereby improving the private sector's sentiments. Subsequently, this encourages more investment spending. As a result, higher investment spending accelerates real GDP. Hence, hypothesis 5's postulation that there is a positive association between fiscal deficit and GDP is supported. Thus, the Keynesian Growth Theory is valid in Malaysia.

Moreover, the positive influence of fiscal deficit (F.D.) on real GDP remains robust after controlling the effect of the 1997-98 Asian Financial Crisis (AFC) and 2008-09 Global Financial Crisis (GFC) in model 3 to model 5.

Next, by looking at the interaction term in models 3,4 , and 5 , the fiscal deficit is found to be growth-enhancing during the economic crisis. Therefore, a fiscal deficit which accelerates capital accumulation is essential in helping the Malaysian economy to recover from the economic crisis.

Turning to the diagnostic checks, from model 2 to model 5, they pass the Breusch-Godfrey LM test and Ramsey RESET test at 1 percent. Therefore, the models are free from autocorrelation errors and are correctly specified. Moreover, the CUSUM of Square test indicates that all the models are stable. 
Table 8: Ordinary Least Square Results

\begin{tabular}{lccccc}
\hline \multirow{2}{*}{ Variables } & $(1)$ & $(2)$ & $(3)$ & $(4)$ & $(5)$ \\
\cline { 2 - 6 } Constant & $4.017^{* * *}$ & $0.352^{* *}$ & 0.134 & $0.412^{* *}$ & 0.213 \\
& $(0.000)$ & $(0.048)$ & $(0.367)$ & $(0.016)$ & $(0.127)$ \\
FD & $0.014^{*}$ & $0.003^{*}$ & $0.003^{* *}$ & $0.003^{*}$ & $0.003^{* * *}$ \\
& $(0.076)$ & $(0.066)$ & $(0.011)$ & $(0.060)$ & $(0.009)$ \\
Ln RER & $1.105^{* * *}$ & 0.047 & 0.057 & 0.044 & 0.047 \\
& $(0.000)$ & $(0.317)$ & $(0.163)$ & $(0.320)$ & $(0.216)$ \\
Ln INT & $-0.749^{* * *}$ & $-0.104^{* * *}$ & $-0.057^{* *}$ & $-0.111^{* * *}$ & $-0.066^{* * *}$ \\
& $(0.000)$ & $(0.000)$ & $(0.013)$ & $(0.000)$ & $(0.002)$ \\
Ln INV & $0.467^{* * *}$ & $0.115^{* * *}$ & $0.095^{* * *}$ & $0.111^{* * *}$ & $0.089^{* * *}$ \\
& $(0.005)$ & $(0.000)$ & $(0.001)$ & $(0.000)$ & $(0.001)$ \\
Ln GDP(-1) & - & $0.895^{* * *}$ & $0.934^{* * *}$ & $0.889^{* * *}$ & $0.928^{* * *}$ \\
& & $(0.000)$ & $(0.000)$ & $(0.000)$ & $(0.000)$ \\
AFC & - & - & $-0.078^{* * *}$ & - & $-0.069^{* * *}$ \\
& & & $(0.000)$ & & $(0.000)$ \\
AFC*FD & - & - & $0.020^{* *}$ & - & $0.021^{* * *}$ \\
& & & $(0.015)$ & & $(0.007)$ \\
GFC & - & - & - & $0.215^{* *}$ & $0.174 * *$ \\
& & & & $(0.035)$ & $(0.028)$ \\
GFC*FD & - & - & - & $0.042^{* *}$ & $0.035^{* *}$ \\
& & & & $(0.019)$ & $(0.014)$ \\
\hline Adjusted R-square & 0.949 & 0.998 & 0.998 & 0.998 & 0.999 \\
Breusch-Godfrey LM test & $10.247^{* * *}$ & 0.644 & 0.369 & 0.255 & 0.024 \\
& $(0.001)$ & $(0.422)$ & $(0.543)$ & $(0.614)$ & $(0.876)$ \\
Ramsey RESET test & 0.007 & 2.047 & 2.235 & 4.119 & 5.621 \\
& $(0.936)$ & $(0.163)$ & $(0.146)$ & $(0.052)$ & $(0.025)$ \\
CUSUM of Square test & Stable & Stable & Stable & Stable & Stable \\
\hline
\end{tabular}

Notes: ${ }^{*},{ }^{* *}$ and ${ }^{* * *}$ denote statistical significance at $10 \%, 5 \%$ and $1 \%$ level respectively. Values in parentheses are p-value. Ln denotes all series is transformed into a natural logarithm. GDP (-1) denotes lag of Malaysia's real GDP. AFC and GFC denote dummy variable for the 1997-98 and 2008-09 economic crisis, respectively.

\section{Conclusion}

Using data from 1980 to 2017, this study examines the linkages between fiscal deficit and economic growth in Malaysia. This paper consists of two significant contributions. Firstly, this paper reveals the long-run relationship in the deficitgrowth nexus in Malaysia. Secondly, this study provides new evidence on the impact of fiscal deficit on Malaysia's GDP.

The empirical results indicate that there is a long-run relationship between fiscal deficit and real GDP. Secondly, on the short-run dynamics, there is information flow from fiscal deficit to real GDP. On the other macroeconomic indicators, the fiscal deficit is found to precede the real interest rate. 
After establishing the information flow from fiscal deficit to GDP, this paper further estimates the impact of fiscal deficit on Malaysia's GDP. Notably, the Keynesian Growth Theory is valid in Malaysia. In particular, there is a positive association between fiscal deficit and Malaysian GDP. Moreover, the fiscal deficit is found to be growth-enhancing during the 1997-98 and 2008-09 economic crisis.

The empirical results suggest that the fiscal deficit plays a vital role in affecting the Malaysian real GDP and interest rate. In particular, our result concurs with earlier work done by Rana and Wahid (2017) in which there is information flow from fiscal deficit to the country's GDP.

Moreover, our study shares the same results with earlier work done by Taylor, Proano, Carvalho and Barbosa (2012) in which there is a positive association between fiscal deficit and GDP. Our results show that a higher fiscal deficit stimulated the economy during the 1997-98 and 2008-09 economic crisis period.

While fiscal deficit may have its role to play in when there is a shock to the economy, as evidenced by the Malaysian economy's recovery in the 1997-98 and 2008-09 episodes of the Asian Financial Crisis and Global Financial Crisis, it is unsuitable to have a prolonged fiscal deficit, as the data has shown. In this respect, efforts must be made to increase the reserve to strengthen the USDMYR exchange rate.

Besides, the additional fiscal spending must be made on activities that will generate a stronger multiplier effect. The lessons from the Asian Financial Crisis must be well remembered by the current leaders so as to not repeat the old mistakes of building up assets, especially in real estate, which cannot be utilised or generate any income for the people.

As a policy suggestion, fiscal deficit results from fiscal expansions should be countercyclical to smooth the business cycle. During bad times, the higher fiscal deficit will improve the performance of macroeconomic indicators, thereby stimulating Malaysia's economic growth. In contrast, some restrictions on fiscal spending must be put in place to increase the national reserve and indirectly strengthen currency value during good times.

\section{References}

Adam, C. S., \& Bevan, D. L. (2005). Fiscal deficits and growth in developing countries. Journal of Public Economics, 89(4), 571-597. 
Fatima, G., Ahmed, M., \& Rehman, W. (2012). Consequential effects of budget deficit on the economic growth of Pakistan. International Journal of Business and Social Science, 3(7), 203-208.

Hallam, D., \& Zanoli, R. (1993). Error-correction models and agricultural supply response. European Review of Agricultural Economics, 69(1), 27-49.

Johansen, S. (1988). Statistical analysis of cointegrating vector. Journal of Economic Dynamic and Control, 12(2-3), 231-254.

Kwiatkowski, D., Philips, P. C. B., Schmidt, P., \& Shin, Y. (1992). Testing the null hypothesis of stationarity against the alternative of a unit root. Journal of Econometrics, 54(1-3), 159-178.

Lau, W. Y. (2007). An integrated framework for style analysis: how is it useful to Malaysian equity trust investors? Managerial Finance, 33(2), 122-141.

Martin, R., \& Fardmanesh, M. (1990). Fiscal variables and growth: A crosssectional analysis. Public Choice, 64(3), 239-251.

Majumder, A. (2007). Does public borrowing crowd-out private investment? Bangladesh evidence (Working Paper No. 0708). Dhaka: Bangladesh Bank.

Mohanty, R. K. (2018). Fiscal deficit and economic growth linkages in India: Impact of FRBM Act. In N. A. Khan (Ed.), Challenges and issues in Indian fiscal federalism (pp. 89-105). Singapore: Springer.

Nelson, M. A., \& Singh, R. D. (1994). The deficit-growth connection: Some recent evidence from developing countries. Economic Development and Cultural Change, 43(1), 167-191.

Obben, J. (1998). The demand for money in Brunei. Asian Economic Journal, 12(2), 109-121.

Rana, E. A., \& Wahid, A. N. M. (2017). Fiscal deficit and economic growth in Bangladesh: A time-series analysis. The American Economist, 62(1), 31-42.

Tan, E. C. (2006). Fiscal deficits, inflation, and economic growth in a successful open developing economy. Review of Applied Economics, 2(1), 129-139.

Taylor, L., Proano, C. R., Carvalho, L. D., \& Barbosa, N. (2012). Fiscal deficits, economic growth, and government debt in the USA. Cambridge Journal of Economics, 36(11), 189-204.

Van, V. B., \& Sudhipongpracha, T. (2015). Exploring government budget deficit and economic growth: Evidence from Vietnam's economic miracle. Asian Affairs: An American Review, 42(3), 127-148. 